\title{
Access to basic care for children seen at emergency departments
}

\author{
Maria Helena Kovacs, ${ }^{1}$ Katia V. O. Feliciano, ${ }^{2}$ \\ Sílvia W. Sarinho, ${ }^{3}$ Ana Amélia C. A. Veras ${ }^{4}$
}

\begin{abstract}
Objective: To investigate access to basic actions among children attended at emergency departments, reconstructing their trajectories to contact with the service for the event in question, characterizing links with basic care and the appropriateness of morbidity to the organizational profile of the service attended.

Methods: Cross-sectional study, carried out in November 2002 and from February to May 2003 at five public pediatric emergency services, of a sample of 383 children under five years old, resident in Recife, calculated for an estimated $20 \%$ of appropriate morbidity, $5 \%$ error and $10 \%$ loss. Using standard instruments applied by eight purposely-trained interviewers.

Results: During their trajectories to reach the contact in question, 38.5\% of the children had sought other services, primarily: emergency ( $48.3 \%)$, family health team (19.7\%) and health centers $(17 \%)$, with $18.4 \%$ having experienced difficulties with primary care. $39.4 \%$ only used emergency and at some point $54.4 \%$ had resorted to this type of service. Approximately $88 \%$ are registered with a unit: $34.5 \%$ with the family health team $(56.8 \%$ of these didn't use the service and $25.6 \%$ had sought them), $42 \%$ at health centers $(59.1 \%$ of those didn't use the service and $18.2 \%$ had resorted to them). Only $18.9 \%$ preferred a basic unit when their child was ill, and therefore for the contact in question, the majority had been brought to their preferred service (like/confide in our professionals, geographic accessibility, and quality of care). Just $36.5 \%$ of the demand was defined as appropriate.

Conclusions: Despite of difficulties with the basic network in guaranteeing access and resolution, a substantial part of this spontaneous demand came from the enormous legitimacy of the emergency services as seen by the population.
\end{abstract}

J Pediatr (Rio J). 2005;81(3):251-8: Accessibility, primary care, reference and counter-reference system, healthcare evaluation.

\section{Introduction}

Comprehensiveness, one of the directives of the Brazilian National Health System (SUS - Sistema Único de Saúde), should guide the practice of every professional, the organization of health working processes and governmental responses for the development of an intersector effort to improve living conditions. In the healthcare sector, comprehensiveness is understood as the result of intra-sector work to assure access to care completion,

1. MSc. Universidade de Pernambuco (UPE), Recife, PE, Brazil.

2. PhD. IMIP, Recife, PE, Brazil.

3. PhD. UPE, Recife, PE, Brazil.

4. MSc. UPE, Recife, PE, Brazil.

Financial support: Brazilian Ministry of Health.

Manuscript received Aug 31 2004, accepted for publication Jan 122005.

Suggested citation: Kovacs MH, Feliciano KV, Sarinho SW, Veras AA. Access to basic care for children seen at emergency departments. J Pediatr (Rio J). 2005;81:251-8. both at the units, by means of the healthcare team, and through the service network, by means of the referral and counter-referral system. ${ }^{1,2}$ In these circumstances, it would be the result of connecting up the services, each one "doing their bit".

Therefore, the health units responsible for primary care would be run at a suitable level of care, presuming high level of resolution of basic demands and acting as an "entrance portal" to secondary care (specialized clinics, diagnosis and therapy support services, some emergency units) and tertiary (more complex hospital services), requiring high diagnostic sensitivity in order to achieve correct referrals within the care system. ${ }^{3}$ Medium and high complexity services are understood as places to offer the specialized care needed at that moment.

Despite the significant advances achieved in the process of decentralization, ${ }^{4}$ more than anything based on the family healthcare strategy, the relationship between supply and demand in the basic network continues to express the 
conflict of interests and needs, 5,6 which results in services of higher technological density being used for healthcare problems that, seen from a technical point of view, could be solved at the primary level. "Receptivity" is a proposal for reorganizing services in order to guarantee access, resolution and humanized care, is an attempt to minimize these obstacles. ${ }^{7}$ Notwithstanding, putting to one side the problems of the service network, spontaneous demand itself expresses different ways of conceiving, prioritizing and acting in the presence of sickness. $1,2,8,9$

The contradictions in the relations between professionals and services have repercussions for the implementation of the SUS, ${ }^{9}$ since practices consolidated within the daily work routine are insufficient to meet the needs of operating with a power of resolution in excess of its immediate demands. The hierarchal network level of resolution, at each level and for the system as a whole, is linked with technical quality defined according to criteria and standards, interpersonal relations, globality and continuity in the utilization of the available resources, added to the knowledge, experience and concepts that guide decisions on healthcare and disease management, in a given sociocultural context.

These aspects are more than just interactions between supply and demand in the care of children, with specialized clinics and walk-in services being important entrances to the health system. In $1996,66.5 \%$ of the pediatric consultations at the Emergency Room of the Hospital Municipal de Volta Redonda (RJ) were neither urgent nor emergencies. ${ }^{2}$ The experiences of referred children also gives evidence of limitations in the realization of the tiered system. At the Pediatric Emergency Department of the Instituto Materno Infantil de Pernambuco, in 1994, $70.7 \%$ of the children arrived there having been referred by second and third level public units, in $32.3 \%$ of the cases without specifying a reason and in $25,6 \%$ because of lack of a pediatrician. 10

At the Hospital Municipal Jesus (RJ), a pediatric center of excellence offering secondary and tertiary care, spontaneous demand accounted for $56.8 \%$ of children who sought care. Triage did not observe fundamental criteria, such as prioritizing referred children, employing risk-focused practices, avoiding unnecessary referrals and facilitating appointment making and neither was triage performed at all times, therefore becoming one of the primary barriers preventing referred children from reaching the service's specialists. Furthermore, the children were not given scheduled appointments to return to the general clinic soon after being seen. ${ }^{11}$

In 1996, a study was undertaken in the state of Pernambuco of fourteen healthcare units, two of which were in the city of Recife. The units were running diarrhea control programs and it was observed that there was a high frequency of refusal of the demand of children under 5 in addition to a requirement to arrive very early to obtain an appointment together with long delays before being seen. There was no formal referral system and the choice of which service the children were referred to was, in $85.7 \%$ of cases, down to the healthcare professional. ${ }^{12}$ Without a doubt these organizational obstacles are important motives for the population to prefer to go straight to those services that operate 24 hours a day.

Portraying the vulnerability of the infant population that continues to fall ill and die from avoidable causes, all of these issues cannot be ignored when discussing the reorganization of the hierarchal healthcare network. For this reason, this evaluative research aimed to investigate the access to basic care available to children seen at emergency services, reconstructing their trajectories via other healthcare units before arriving at the emergency department and describing links with basic care and appropriateness of morbidity to the organizational profile of the services. It is hoped to thereby contribute towards the design of new circuits within the healthcare system.

\section{Methodology}

A descriptive, cross-sectional study undertaken at the five public centers of excellence for pediatric emergency: Hospital de Pediatria Helena Moura (HPHM) and the Hospital de Pediatria Maria Cravo Gama (HPMCG), both secondary care services whose demand originates from Recife and its surrounding area, the Hospital Barão de Lucena (HBL), the Instituto Materno Infantil de Pernambuco (IMIP) and the Hospital da Restauração (HR), tertiary hospitals serving the state of Pernambuco. For each service sample size was calculated based on the mean number of emergency room consultations, based on data from 2001 and the first six months of 2002, an estimated $20 \%$ of morbidity appropriate to the level of complexity of the service, $5 \%$ error and $10 \%$ losses. ${ }^{13}$

Children were selected from a list of all those aged up to 4 years, 11 months and 29 days, residents of Recife, who sought care and provided name, age and place of residence. The first eligible child who arrived after the start of data collection was selected and then, after a fixed number of eligible patients, the "sample ratio", the next was chosen, and so on. Four children were excluded (parents or guardians did not wait to be seen and medical records lacking necessary information). Data was collected uninterruptedly from identification of the first eligible child, during November 2002 and from February to May in 2003, spending an average of two weeks at each healthcare unit.

If the child selected had been enrolled on the study on a previous occasion at the same service or in the event of any misunderstanding in filling out information relating to inclusion criteria when filling out the record for that contact, or if the person responsible for the child refused permission to participate - there were three refusals - the next child presenting at the service who met the criteria was chosen and the "sample ratio" interval was counted from the excluded or refused case. The sample totaled 383 children. The project was approved by the Committee for Ethics in Research at the IMIP on 02/11/2002.

The questionnaire contained information from: 1) the people who had brought the children - age, sex, address and 
relationship with the responsible adult; age, sex, education of the responsible adult, type of demand, services used for this episode including open questions on the reasons for choosing the service at which the patient was enrolled, the healthcare unit at which the child was registered, why that had been chosen, which service was preferred when ill and the reasons for this preference, all of which were recorded and transcribed in full by the interviewer; and 2) from medical records - diagnosis and medical conduct. The interviewees gave free and informed consent. The fieldwork team was made up of supervisor and eight interviewers with experience of research and duly trained. A pilot study was performed and quality control was applied to sampling, collection and transcription of recordings.

Three pediatricians assessed the appropriateness of morbidity to the technological capacity of the service, taking account of: day and time of consultation, child's age, duration of disease, previous contact with the same service, demand for referral, diagnostic hypotheses and conduct during the contact being investigated. Demand could be defined as appropriate or not according to one of five categories: 1) appropriate due to type of occurrence (accident, violence, convulsions, poisoning, bitten by snake/ scorpion, bronchiolitis in infants less than 6 months old, events requiring hospital admission, referral from other emergency unit, venous hydration and corticoid injections); 2) appropriate because following medical instructions (referral); 3) appropriate because of time (the basic healthcare network could have dealt with the problem, but demand was Monday to Friday between 17:00 and 08:00; 4) appropriate because of day (similar to the previous except that demand occurred at the weekend); and 5) inappropriate (requirements were for outpatients/ ambulatory care).

Responses to questions pre-coded with the option "other" were given a specific code and open questions were studied to map emerging "meaning clusters". 14 Results were sent for thematic analysis and meaning clusters were counted and the resulting variables input to a matrix constructed with Epi-Info 6.04 software. Variables were crossed with the services attended during the episode investigated. When the children cared for at the five units were compared, significant differences were identified between: a) medians with Kruskal-Wallis analysis of variance; and b) proportions with chi-square. The term "tendency" was used to describe results that exhibited differences without statistical significance.

\section{Results}

The majority of the children (56.7\%) were female, with a median age of 19 months and an interval of 9 to 35 months between the first and fourth quartiles and $15.6 \%$ less than five months old. With respect of the contact investigated, $55.9 \%$ of patients were attending the center of excellence for their local Health District, $95.8 \%$ attended with responsible adults who were predominantly women $(95.8 \%)$, were aged between 14 and 60 years, giving a median age of 25 years,
$18.8 \%$ of whom were younger than 20 and having a median of 6 years' schooling, with $1.4 \%$ never having studied and $9.9 \%$ who were illiterate, being, in $91.9 \%$ of cases the mother, in $3.8 \%$ a grandparent and in $2.7 \%$, the father. Of the $31.8 \%$ who were employed, $31.2 \%$ worked up to 20 hours a week, $19.6 \%$ from 21 to 40 and $49.2 \%$ worked more than 41 hours a week.

There was no difference between the units in terms of median time passed between the start of the event and the child's first contact with the health service. This figure was 48 hours, with the interval between first and third quartile being from 24 to 72 hours. The same was true of those children who had already sought care $(38.5 \%)$, with respect of the median time between the start of the event and the contact with the emergency department being investigated. This figure was 96 hours, with the interval between first and third percentiles being from 72 to 168 hours.

The motives given for choosing the service where the interview was performed were general quality of service ("this is a good center", "the service is better", "it's got more resources", "it's very well respected" and "it treats the children well"); geographical accessibility, which was more often mentioned at the HPMCG and HBL and previous personal experience, at the IMIP and $\mathrm{HBL}$; the quality of medical care ("they examine well", "the treatment is always right" and "they do tests"), exhibiting a strong tendency to value the HR and IMIP more, and previous experience of the social network at the IMIP; availability of the pediatrician; level of resolution of the service, mentioned exclusively at the IMIP and the HR; and access to medication (Table 1).

During their trajectories to arrive at the consultation under investigation, $61.5 \%$ had not used other health services, this being more common at the HPMCG and the $\mathrm{HBL}$, while just $2.1 \%$ had used community health agents. Previous contact with two or more other services was greatest at the IMIP and the HR. Practically half of the children who sought care made first contact at emergency services; followed by the family health service, most used at the HBL and less at the IMIP and HR; then by health centers, polyclinics and other public and private services. The first contact was made at the basic health network by a large $(54.6 \%)$ proportion at the $\mathrm{HBL}$ and a smaller $(16.2 \%)$ proportion at the IMIP (Table 2 ).

Among those children who had been to another service, $39.4 \%$ had used just emergency departments, while $54.4 \%$ had been to this type of center at some point. The reasons given for this choice were geographical accessibility, previous personal experience, satisfaction with the service, guidance from the social network, alluded to relatively more often at the HPHM, smaller time lag between arrival and consultation, persistence/worsening of the disease and availability of a pediatrician (Table 3).

In their prior contacts with other services $38.8 \%$ of the children had encountered problems, of which $47.4 \%$ were with the basic network, mentioned relatively more at the HPMCG $(83.3 \%)$ and the HBL $(62.5 \%)$ and less at the IMIP $(27.8 \%)$. The greatest problems were appointments being made for a different day (33.3\%), no 
Table 1 - Motives given for choosing pediatric emergency services according to healthcare unit. Recife, 2003

\begin{tabular}{|c|c|c|c|c|c|c|c|c|c|c|c|c|}
\hline \multirow[t]{2}{*}{ Variables } & \multicolumn{2}{|c|}{ HPHM } & \multicolumn{2}{|c|}{ HPMCG } & \multicolumn{2}{|c|}{ HBL } & \multicolumn{2}{|c|}{ IMIP } & \multicolumn{2}{|c|}{ HR } & \multicolumn{2}{|c|}{ Total } \\
\hline & $\mathbf{n}$ & $\%$ & $\mathbf{n}$ & $\%$ & $\mathbf{n}$ & $\%$ & $\mathbf{n}$ & $\%$ & $\mathbf{n}$ & $\%$ & $\mathbf{n}$ & $\%$ \\
\hline \multicolumn{13}{|l|}{ Motives for choosing this service } \\
\hline Quality of service & 54 & 57.4 & 39 & 54.2 & 42 & 57.5 & 44 & 60.3 & 37 & 52.1 & 216 & 56.4 \\
\hline Geographic accessibility * & 34 & 36.2 & 42 & 58.3 & 42 & 57.5 & 15 & 20.5 & 21 & 29.6 & 154 & 42.0 \\
\hline Previous personal experience $^{+}$ & 22 & 23.4 & 8 & 11.1 & 23 & 31.5 & 26 & 35.6 & 12 & 16.9 & 91 & 24.8 \\
\hline Quality of medical care ${ }^{\ddagger}$ & 13 & 13.8 & 14 & 19.2 & 10 & 13.7 & 19 & 26.0 & 20 & 28.2 & 76 & 20.7 \\
\hline $\begin{array}{l}\text { Previous experience } \\
\text { of the social network } \S\end{array}$ & 11 & 11.7 & 9 & 12.5 & 7 & 9.6 & 16 & 21.9 & 5 & 7.0 & 48 & 13.1 \\
\hline Pediatrician available & 5 & 5.3 & - & - & - & - & 11 & 15.1 & 3 & 4.2 & 19 & 5.2 \\
\hline Resolution capacity & - & - & - & - & - & - & 10 & 13.7 & 7 & 9.9 & 17 & 4.6 \\
\hline
\end{tabular}

HPHM = Hospital Pediátrico Helena Moura; HPMCG = Hospital Pediátrico Maria Cravo Gama; HBL = Hospital Barão de Lucena; IMIP = Instituto Materno Infantil de Pernambuco; HR = Hospital da Restauração.
* $\left(\chi^{2}=34.67 ; p=0.000\right)$
$\dagger\left(\chi^{2}=16.29 ; p=0.003\right)$
$\ddagger\left(\chi^{2}=8.73 ; p=0.068\right)$
$\S\left(\chi^{2}=8.45 ; p=0.076\right)$

Table 2 - Trajectory to reach the contact with the emergency service according to healthcare unit. Recife, 2003

\begin{tabular}{|c|c|c|c|c|c|c|c|c|c|c|c|c|}
\hline \multirow[t]{2}{*}{ Variables } & \multicolumn{2}{|c|}{ НРНМ } & \multicolumn{2}{|c|}{ HPMCG } & \multicolumn{2}{|c|}{ HBL } & \multicolumn{2}{|c|}{ IMIP } & \multicolumn{2}{|c|}{ HR } & \multicolumn{2}{|c|}{ Total } \\
\hline & $\mathbf{n}$ & $\%$ & $\mathbf{n}$ & $\%$ & $\mathbf{n}$ & $\%$ & $\mathbf{n}$ & $\%$ & $\mathbf{n}$ & $\%$ & $\mathbf{n}$ & $\%$ \\
\hline \multicolumn{13}{|c|}{ Sought the community health agent: } \\
\hline Yes & 4 & 4.3 & 2 & 2.8 & 1 & 1.4 & - & - & 1 & 1.4 & 8 & 2.1 \\
\hline Not & 90 & 95.7 & 70 & 97.2 & 72 & 98.6 & 73 & 100.0 & 70 & 98.6 & 375 & 97.9 \\
\hline \multicolumn{13}{|c|}{$\begin{array}{l}\text { Number of previous contacts } \\
\text { with services: }\end{array}$} \\
\hline $0 *$ & 56 & 59.6 & 53 & 73.6 & 51 & 69.9 & 36 & 49.4 & 40 & 56.4 & 236 & 61.5 \\
\hline 1 & 21 & 22.3 & 16 & 22.2 & 20 & 27.4 & 25 & 34.2 & 22 & 31.0 & 104 & 27.2 \\
\hline 2 and $^{\text {more }}{ }^{\dagger}$ & 17 & 18.1 & 3 & 4.2 & 2 & 6.7 & 12 & 16.4 & 9 & 12.6 & 43 & 11.3 \\
\hline \multicolumn{13}{|l|}{ Type of first contact: ${ }^{\ddagger}$} \\
\hline Family health unit ${ }^{\ddagger}$ & 10 & 26.3 & 6 & 31.5 & 8 & 36.4 & 2 & 5.4 & 3 & 9.7 & 29 & 19.7 \\
\hline Health center & 6 & 15.8 & 3 & 15.8 & 4 & 18.2 & 4 & 10.8 & 8 & 25.8 & 25 & 17.0 \\
\hline Polyclinics & 2 & 5.3 & 1 & 5.3 & - & - & 7 & 18.9 & 2 & 6.5 & 12 & 8.2 \\
\hline Urgency/emergency & 20 & 52.6 & 9 & 47.4 & 8 & 36.4 & 17 & 45.9 & 17 & 54.8 & 71 & 48.3 \\
\hline Outhers & - & - & - & - & 1 & 4.5 & 7 & 19.0 & 1 & 3.2 & 9 & 6.1 \\
\hline No information & - & - & - & - & 1 & 4.5 & - & - & - & - & 1 & 0.7 \\
\hline
\end{tabular}

HPHM = Hospital Pediátrico Helena Moura; HPMCG = Hospital Pediátrico Maria Cravo Gama; HBL = Hospital Barão de Lucena; IMIP = Instituto Materno Infantil de Pernambuco; HR = Hospital da Restauração.

$*\left(\chi^{2}=12.15 ; p=0.016\right)$. $\quad+\left(\chi^{2}=10.57 p=0.032\right) . \quad \neq 236$ children excluded for not having previously used those services.

$\ddagger\left(\chi^{2}=13.34 ; p=0.010\right)$.

consultation being offered at all (25.9\%), appointment made with health agent ( $14.8 \%)$, excess demand $(14.8 \%)$, no doctor $(14.8 \%)$ and no pediatrician $(7.4 \%)$.

The most common reasons given for not using other healthcare services first were: perceptions about the signs and symptoms and expectations of a homemade remedy to solve the problem made such demand unnecessary, with a tendency to be more common at the HPHM and rarer at the $\mathrm{HBL}$, preference for the service in question, with a strong tendency towards the IMIP and away from the HPMCG; obstacles to access at other services and geographic accessibility. Besides, other reasons were the responsible adult's employment, dissatisfaction with conduct and lack of resolution at other services (Table 4 ). 
Approximately $88 \%$ of the children were registered at a healthcare service of some type. Of those registered at family healthcare units, $56.8 \%$ did not seek care at that service and $25.6 \%$ did use it, with proportions being relatively larger at the HPHM and HPMCG. Of those registered at health centers, which was more common at the HR and less so at the HBL, $59.1 \%$ did not use the service, particularly so at the HPMCG and $18.2 \%$ did present at the center (Table 5).

Almost all of the responsible adults (99.7\%) prefer to take sick children to a specific health service, giving priority to specialized units, public hospitals and charity

Table 3 - Previous use of emergency services according to healthcare unit. Recife. 2003

\begin{tabular}{|c|c|c|c|c|c|c|c|c|c|c|c|c|}
\hline \multirow[t]{2}{*}{ Variables* } & \multicolumn{2}{|c|}{ HРHM } & \multicolumn{2}{|c|}{ HPMCG } & \multicolumn{2}{|c|}{ HBL } & \multicolumn{2}{|c|}{ IMIP } & \multicolumn{2}{|c|}{ HR } & \multicolumn{2}{|c|}{ Total } \\
\hline & $\mathbf{n}$ & $\%$ & $\mathbf{n}$ & $\%$ & $\mathbf{n}$ & $\%$ & $\mathbf{n}$ & $\%$ & $\mathbf{n}$ & $\%$ & $\mathbf{n}$ & $\%$ \\
\hline \multicolumn{13}{|l|}{ Only emergency service: } \\
\hline Yes & 12 & 31.6 & 8 & 42.1 & 7 & 31.8 & 16 & 43.2 & 15 & 48.4 & 58 & 39.4 \\
\hline No & 26 & 68.4 & 11 & 57.9 & 15 & 68.2 & 21 & 56.8 & 16 & 51.6 & 89 & 60.6 \\
\hline \multicolumn{13}{|l|}{ Also emergency service: } \\
\hline Yes & 24 & 63.1 & 9 & 47.4 & 8 & 36.4 & 20 & 54.1 & 19 & 61.3 & 80 & 54.4 \\
\hline No & 14 & 36.9 & 10 & 52.6 & 14 & 63.6 & 17 & 45.9 & 12 & 38.7 & 67 & 45.6 \\
\hline \multicolumn{13}{|l|}{$\begin{array}{l}\text { Reasons to look for this type } \\
\text { of service: }\end{array}$} \\
\hline Geographic accessibility & 13 & 54.2 & 3 & 33.3 & 5 & 62.5 & 13 & 65.0 & 12 & 63.1 & 46 & 57.5 \\
\hline Previous personal experience & 7 & 29.2 & 1 & 11.1 & 2 & 25.0 & 3 & 15.0 & 4 & 21.0 & 17 & 21.2 \\
\hline Guidance from the social network & 8 & 33.3 & 1 & 11.1 & - & - & 3 & 15.0 & 2 & 10.5 & 14 & 17.5 \\
\hline Satisfaction with the service & 4 & 16.7 & 3 & 33.3 & 1 & 12.5 & 4 & 20.0 & 3 & 15.8 & 15 & 18.7 \\
\hline $\begin{array}{l}\text { Smaller time lag between arrival } \\
\text { and consultation }\end{array}$ & 4 & 16.7 & 2 & 22.2 & 1 & 12.5 & 3 & 15.0 & 1 & 5.3 & 11 & 13.7 \\
\hline $\begin{array}{l}\text { Persistence/worsening } \\
\text { of the disease }\end{array}$ & 2 & 8.3 & - & - & - & - & 4 & 20.0 & 2 & 10.5 & 8 & 10.0 \\
\hline Pediatracian available & & & & & 2 & 25.0 & 1 & 5.0 & 2 & 10.5 & 5 & \\
\hline
\end{tabular}

HPHM = Hospital Pediátrico Helena Moura; HPMCG = Hospital Pediátrico Maria Cravo Gama; HBL = Hospital Barão de Lucena; IMIP = Instituto Materno Infantil de Pernambuco; HR = Hospital da Restauração.

* 236 children with no previous use of services were excluded.

Table 4 - Reasons given for not using other healthcare services first according to healthcare unit. Recife, 2003

\begin{tabular}{|c|c|c|c|c|c|c|c|c|c|c|c|c|}
\hline \multirow[t]{2}{*}{ Variable* } & \multicolumn{2}{|c|}{ HPHM } & \multicolumn{2}{|c|}{ HPMCG } & \multicolumn{2}{|c|}{ HBL } & \multicolumn{2}{|c|}{ IMIP } & \multicolumn{2}{|c|}{ HR } & \multicolumn{2}{|c|}{ Total } \\
\hline & $\mathbf{n}$ & $\%$ & $\mathbf{n}$ & $\%$ & $\mathbf{n}$ & $\%$ & $\mathbf{n}$ & $\%$ & $\mathbf{n}$ & $\%$ & $\mathbf{n}$ & $\%$ \\
\hline \multicolumn{13}{|l|}{$\begin{array}{l}\text { Reasons given for not using other } \\
\text { healthcare services first: }\end{array}$} \\
\hline It was not considered necessary $^{\dagger}$ & 25 & 44.6 & 21 & 39.6 & 11 & 21.6 & 11 & 30.5 & 11 & 27.5 & 79 & 33.5 \\
\hline Preference for this service ${ }^{\ddagger}$ & 20 & 35.7 & 11 & 20.7 & 20 & 39.2 & 17 & 47.2 & 10 & 25.0 & 78 & 33.0 \\
\hline $\begin{array}{l}\text { Obstacles to access } \\
\text { at other services }\end{array}$ & 17 & 30.3 & 11 & 20.7 & 9 & 17.6 & 5 & 13.9 & 7 & 17.5 & 49 & 20.8 \\
\hline Geographic accessibility & - & - & 15 & 28.3 & 10 & 19.6 & 6 & 16.7 & 8 & 20.0 & 39 & 16.5 \\
\hline Responsible adult's employment & 3 & 5.3 & 6 & 11.3 & 5 & 9.8 & 4 & 11.1 & 3 & 7.5 & 21 & 8.9 \\
\hline $\begin{array}{l}\text { Dissatisfaction with conduct } \\
\text { at other services }\end{array}$ & 4 & 7.1 & 1 & 1.9 & 2 & 3.9 & 4 & 11.1 & 2 & 5.0 & 13 & 5.5 \\
\hline Lack of resolution at other services & 3 & 5.3 & 2 & 3.8 & - & - & 4 & 11.1 & 1 & 2.5 & 10 & 4.2 \\
\hline Distance from other services & 7 & 12.5 & - & - & 2 & 3.9 & 1 & 2.8 & - & - & 10 & 4.2 \\
\hline Not enough money for bus tickets & 1 & 1.8 & 2 & 3.8 & 3 & 5.9 & 1 & 2.8 & 2 & 5.0 & 9 & 3.8 \\
\hline
\end{tabular}

HPHM = Hospital Pediátrico Helena Moura; HPMCG = Hospital Pediátrico Maria Cravo Gama; HBL = Hospital Barão de Lucena; IMIP = Instituto Materno Infantil de Pernambuco; HR = Hospital da Restauração.

* The 147 children who had previously used services were excluded.

$+\left(\chi^{2}=8.06 ; p=0.089\right)$

$\ddagger\left(\chi^{2}=9.12 ; p=0.058\right)$ 
hospitals. Therefore, during the contact being investigated, the majority of children were using their preferred service, especially so at the HBL. This preference is explained by liking/trusting the professionals, less valued at the HR, by geographic accessibility, by speed and quality of service and by previous personal experience and resolution. Just $18.9 \%$ preferred a unit of the basic healthcare network, with this figure being greatest at the HR and smallest at the IMIP (Table 6).

It was found that $63.5 \%$ of the children presented with health problems that could be solved within the basic network, this being relatively higher at the $\mathrm{HBL}(72.6 \%)$ and lower at the HR (49.2\%). Fifteen point two percent of the $36.5 \%$ whose needs were defined as appropriate for the emergency service where they were interviewed needed to be cared for at an emergency department and 3.9\% had been referred there. The remainder had needs that could have been met at the primary level and were considered to have attended appropriately because of the time (7\%) and day that they needed care $(10.4 \%)$ (Table 7$)$.

\section{Discussion}

Like other studies of the profile of morbidities presented by users of emergency departments, ${ }^{2}$ just $15.2 \%$ of the problems that motivated juvenile demand required the technological capacity of unit utilized. Further evidence of the failure to fulfill technical rationalization expectations is the residual character of the referrals. This result is surprising, since, with the expansion of the Family Health Program (FHP) in Recife, and considering that the teams' power of resolution is still restricted, a greater proportion of referrals would be expected in situations that required emergency care.

Aspects of the macro-structural plan that stand out when explaining the extensive spontaneous demand for emergency services - imbalance between growth of the basic network, necessity of care and lack of definition of basic units roles, perceptions of those responsible for children about the FHP (less medical consultation offered and not being used to have the child seen by a nurse), preconceived ideas about the need for emergency care, values relating to the use of pediatric emergency services rooted in the population's imagination ${ }^{2,9}$ - and the services' daily routines - access to the basic network and the quality of care given.

With respect of limited access to primary care, there are four possibilities for conflict of interests between supply and demand that are worth exploring. First, when the child presents a condition that demands attention as quickly as

Table 5 - Availability for registration and use of services, in the current event, of children registered in the basic network, according to healthcare unit. Recife, 2003

\begin{tabular}{|c|c|c|c|c|c|c|c|c|c|c|c|c|}
\hline \multirow[t]{2}{*}{ Variables } & \multicolumn{2}{|c|}{ HРHМ } & \multicolumn{2}{|c|}{ HPMCG } & \multicolumn{2}{|c|}{ HBL } & \multicolumn{2}{|c|}{ IMIP } & \multicolumn{2}{|c|}{ HR } & \multicolumn{2}{|c|}{ Total } \\
\hline & $\mathbf{n}$ & $\%$ & $\mathbf{n}$ & $\%$ & $\mathbf{n}$ & $\%$ & $\mathbf{n}$ & $\%$ & $\mathbf{n}$ & $\%$ & $\mathbf{n}$ & $\%$ \\
\hline \multicolumn{13}{|l|}{$\begin{array}{l}\text { Children registered } \\
\text { in a healthcare service: * }\end{array}$} \\
\hline Yes & 80 & 92.0 & 61 & 87.1 & 65 & 94.2 & 61 & 83.6 & 56 & 82.4 & 323 & 88.0 \\
\hline No & 7 & 8.0 & 9 & 12.9 & 4 & 5.8 & 12 & 16.4 & 12 & 17.6 & 44 & 12.0 \\
\hline \multicolumn{13}{|l|}{ Family healthcare unit } \\
\hline \multicolumn{13}{|l|}{ Children registered: } \\
\hline Yes & 35 & 40.2 & 19 & 22.1 & 35 & 50.7 & 19 & 26.0 & 17 & 25.0 & 125 & 34.1 \\
\hline No & 52 & 59.8 & 51 & 72.9 & 34 & 49.3 & 54 & 74.0 & 51 & 75.0 & 242 & 65.9 \\
\hline \multicolumn{13}{|c|}{ Previous use of healthcare service: ${ }^{\dagger}$} \\
\hline Yes, family healthcare unit & 11 & 31.4 & 6 & 31.6 & 8 & 22.9 & 3 & 15.8 & 4 & 23.5 & 32 & 25.6 \\
\hline Yes, other type & 3 & 8.6 & 2 & 10.5 & 4 & 11.4 & 8 & 42.1 & 5 & 29.4 & 22 & 17.6 \\
\hline \multicolumn{13}{|l|}{ Healthcare center } \\
\hline \multicolumn{13}{|l|}{ Children registered: } \\
\hline Yes & 39 & 44.8 & 31 & 44.3 & 19 & 27.5 & 29 & 39.7 & 36 & 52.9 & 154 & 42.0 \\
\hline No & 48 & 55.2 & 39 & 55.7 & 50 & 72.5 & 44 & 60.3 & 32 & 47.1 & 213 & 58.0 \\
\hline \multicolumn{13}{|c|}{ Previous use of healthcare service: $\dagger \neq$} \\
\hline Yes, healthcare center & 9 & 23.1 & 2 & 6.4 & 3 & 15.8 & 6 & 20.7 & 8 & 22.2 & 28 & 18.2 \\
\hline Yes, other type & 10 & 25.6 & 3 & 9.7 & 4 & 21.0 & 10 & 34.5 & 8 & 22.2 & 35 & 22.7 \\
\hline No & 20 & 51.3 & 26 & 83.9 & 12 & 63.2 & 13 & 44.8 & 20 & 55.6 & 91 & 59.1 \\
\hline
\end{tabular}

HPHM = Hospital Pediátrico Helena Moura; HPMCG = Hospital Pediátrico Maria Cravo Gama; HBL = Hospital Barão de Lucena; IMIP = Instituto Materno Infantil de Pernambuco; HR = Hospital da Restauração.

* The 16 children who were not referred to services with their responsibles were excluded.

$\dagger$ The 44 children who were not registered in healthcare services were excluded.

$\ddagger\left(\chi^{2}=11,62 ; p=0,020\right)$. 
Table 6 - Preferred service and reasons for choosing it when the children is sick, according to healthcare unit. Recife, 2003

\begin{tabular}{|c|c|c|c|c|c|c|c|c|c|c|c|c|}
\hline \multirow[t]{2}{*}{ Variables* } & \multicolumn{2}{|c|}{ НРНM } & \multicolumn{2}{|c|}{ HPMCG } & \multicolumn{2}{|c|}{ HBL } & \multicolumn{2}{|c|}{ IMIP } & \multicolumn{2}{|c|}{ HR } & \multicolumn{2}{|c|}{ Total } \\
\hline & $n$ & $\%$ & $n$ & $\%$ & $\mathbf{n}$ & $\%$ & $n$ & $\%$ & $\mathbf{n}$ & $\%$ & $\mathbf{n}$ & $\%$ \\
\hline \multicolumn{13}{|l|}{$\begin{array}{l}\text { Preferred service } \\
\text { when the child is sick: }\end{array}$} \\
\hline Family health unit & 11 & 12.7 & 2 & 2.9 & 7 & 10.2 & 2 & 2.8 & 8 & 11.8 & 30 & 8.2 \\
\hline Healthcare center & 11 & 12.7 & 7 & 10.0 & 3 & 4.3 & 5 & 7.0 & 13 & 19.1 & 39 & 10.7 \\
\hline Polyclinics & 3 & 3.4 & - & - & 1 & 1.4 & 6 & 8.3 & 2 & 2.9 & 12 & 3.3 \\
\hline Specialized units & 49 & 56.3 & 49 & 70.0 & 1 & 1.4 & 8 & 11.1 & 8 & 11.8 & 115 & 31.4 \\
\hline Private services & 3 & 3.4 & 1 & 1.4 & 1 & 1.4 & 2 & 2.8 & - & - & 7 & 1.9 \\
\hline Public hospital ${ }^{+}$ & 4 & 4.6 & 2 & 2.9 & 54 & 78.4 & 8 & 11.1 & 29 & 42.6 & 97 & 26.5 \\
\hline Charity hospital & 2 & 2.3 & 9 & 12.8 & 2 & 2.9 & 40 & 55.5 & 7 & 10.3 & 60 & 16.4 \\
\hline Not informed & 4 & 4.6 & - & - & - & - & 1 & 1.4 & 1 & 1.5 & 6 & 1.6 \\
\hline \multicolumn{13}{|l|}{ Reasons for preference } \\
\hline Like/Trust the professionals ${ }^{\ddagger}$ & 27 & 31.0 & 28 & 40.0 & 33 & 47.8 & 35 & 48.1 & 18 & 26.5 & 141 & 38.5 \\
\hline Geographic accessibility & 33 & 37.9 & 27 & 38.6 & 23 & 33.3 & 22 & 30.5 & 30 & 44.1 & 135 & 36.9 \\
\hline Quality of service & 34 & 39.1 & 19 & 27.1 & 21 & 30.4 & 24 & 33.3 & 19 & 27.9 & 117 & 32.0 \\
\hline Smaller time lag between & & & & & & & & & & & & \\
\hline arrival and consultation & 14 & 16.1 & 8 & 11.4 & 4 & 5.8 & 6 & 8.3 & 8 & 11.8 & 40 & 10.9 \\
\hline Previous personal experience & 7 & 8.0 & 9 & 12.9 & 5 & 7.2 & 8 & 11.1 & 6 & 8.8 & 35 & 9.6 \\
\hline Resolution capacity & 2 & 2.3 & 4 & 5.7 & 4 & 5.8 & 3 & 4.2 & 4 & 5.9 & 17 & 4.6 \\
\hline
\end{tabular}

HPHM = Hospital Pediátrico Helena Moura; HPMCG = Hospital Pediátrico Maria Cravo Gama; HBL = Hospital Barão de Lucena;

IMIP = Instituto Materno Infantil de Pernambuco; HR = Hospital da Restauração.

* The 16 children who were not referred to services with their responsibles were excluded.

$\dagger\left(\chi^{2}=154.84 ; p=0.000\right)$;

$\neq\left(\chi^{2}=12.37 ; p=0.015\right)$.

Table 7 - Supply and demand according to healthcare unit. Recife. 2003

\begin{tabular}{|c|c|c|c|c|c|c|c|c|c|c|c|c|}
\hline \multirow[t]{2}{*}{ Variable } & \multicolumn{2}{|c|}{ НРНМ } & \multicolumn{2}{|c|}{ HPMCG } & \multicolumn{2}{|c|}{ HBL } & \multicolumn{2}{|c|}{ IMIP } & \multicolumn{2}{|c|}{ HR } & \multicolumn{2}{|c|}{ Total } \\
\hline & $\mathbf{n}$ & $\%$ & $\mathbf{n}$ & $\%$ & $\mathbf{n}$ & $\%$ & $\mathbf{n}$ & $\%$ & $\mathbf{n}$ & $\%$ & n & $\%$ \\
\hline \multicolumn{13}{|l|}{ Required emergency care: } \\
\hline $\begin{array}{l}\text { Yes, due to the patient's } \\
\text { conditions }\end{array}$ & 16 & 17.0 & 10 & 13.9 & 10 & 13.7 & 8 & 11.0 & 14 & 19.8 & 58 & 15.2 \\
\hline $\begin{array}{l}\text { Yes, patient referred to an } \\
\text { emergency department }\end{array}$ & 2 & 2.1 & 1 & 1.4 & 1 & 1.4 & 6 & 8.2 & 5 & 7.0 & 15 & 3.9 \\
\hline $\begin{array}{l}\text { Yes, because of the time } \\
\text { they needed care }\end{array}$ & 4 & 4.3 & 5 & 6.9 & 4 & 5.5 & 4 & 5.5 & 10 & 14.1 & 27 & 7.0 \\
\hline $\begin{array}{l}\text { Yes, because of the day } \\
\text { they needed care }\end{array}$ & 9 & 9.6 & 10 & 13.9 & 5 & 6.8 & 9 & 12.3 & 7 & 9.9 & 40 & 10.4 \\
\hline No & 63 & 67.0 & 46 & 63.9 & 53 & 72.6 & 46 & 63.0 & 35 & 49.2 & 243 & 63.5 \\
\hline
\end{tabular}

HPHM = Hospital Pediátrico Helena Moura; HPMCG = Hospital Pediátrico Maria Cravo Gama; HBL = Hospital Barão de Lucena;

IMIP = Instituto Materno Infantil de Pernambuco; HR = Hospital da Restauração.

possible, that could be resolved at the primary care level, but at a time or on a day when these units are closed, making the use of the emergency department appropriate. In the present study, these two possibilities accounted for just $17.4 \%$ of cases. Second, since the majority of the children had not used any other service for the event in question, this could be associated with their parents/guardians being employed. However, just $38.6 \%$ of them were employed and very few referred to employment to explain why they had not used a different service.
Third, related to the organization of care, the relationship between user and team and/or healthcare professional and expectations about the service's capacity to meet immediate needs. 5,6 In this sense, problems accessing the basic network were important reasons for not having tried a different service first. These perceptions certainly stimulated great demand of children seeking emergency services. The experiences of family members, friends and neighbors influenced the utilization of services. ${ }^{8}$ Fourth, despite the expansion of the FHP, geographical access has a weight in 
the choice not to seek other services for the event in question: for $42 \%$ the units where they were interviewed were the closest to their homes, with this proximity possibly representing the principal motive for the choice. Geographical access was fundamental to the choice of emergency service attended for the episode in question.

Practically all of the children were registered in some health service, suggesting that their parents/guardians were aware of the public service network. Nevertheless, the use of the service at which the children were registered for the event in question was small. This behavior, in part, is the result of access difficulties, lack of appointments for consultations by the community health agent for the sick children - minimal mention - or, in the case of the health centers, the result of parents/guardians who did not want or were not able to wait for the time between making an appointment and consultation, or waiting in the queue to do so and not being given an appointment for that day. 9,12

Nevertheless, the principal motive for not taking sick children to the service at which they were registered was the parents' or guardians' preference for units with higher technological density. During the contact being studied, the majority of children used the preferred service, principally due to confidence in the professionals, expectations about quality of care, personal experience and/or of the social network, satisfaction with service and also geographical accessibility. This positive image of the emergency department services, in evidence through their enormous legitimacy in the eyes of the population, 2,9 is reinforced when: a) the preference for this service is the reason for not having taken the child to a different service during the event in question; and b) practically half of those who did use services sought pediatric emergency units.

Technically inappropriate demand has repercussions for the quality of care given to those that really do need emergency care and those whose ambulatory care is restricted to that complaint, compromising integrated care since these services do not routinely counter-refer, not having any formal connection to primary care. It is in this context that much has been discussed with relation to the competencies of the basic health units within the hierarchy of the healthcare network, with a confrontation remaining between a vision that holds this level, almost exclusively, responsible for programs aimed at specific diseases/population groups, and another vision that expects the simultaneous development of programmed interventions and on-demand care. ${ }^{2}$

Since people do not passively receive healthcare actions, and, within certain limits, adopt their own criteria for choosing the services they use, it is essential to understand the reasons on which these preferences in questions of healthcare and disease are founded, exploring this wide and complex world of possibilities and impossibilities that includes meanings, values and day-to-day contingencies. ${ }^{8,9,15}$ In order that hierarchy be not merely one more wish of the technicians, it is necessary to understand that the organization of the healthcare system passes through questioning as to what are necessities from the points of view of the care model and of the user. ${ }^{2,15}$

\section{Acknowledgements}

Thanks to the fieldworkers: Albanira Maria Alves, Cláudia Maria de Lima, Manoel Alexandre Arruda Neto, Mary Helen Nascimento de França, Paula de Cássia Mendes de Moura, Regina Lúcia Carvalho de Lima, Rosete Bibiana de Melo, Rosilda de Oliveira and to the Health Ministry for financial support.

\section{References}

1. Cecílio LCO. As necessidades de saúde como conceito estruturante na luta pela integralidade e eqüidade na atenção em saúde. In: Pinheiro R, Mattos RA, orgs. Os sentidos da integralidade na atenção e no cuidado à saúde. Rio de Janeiro: UERJ, IMS: ABRASCO; 2001. p. 113-26.

2. Cecílio LCO. Modelos tecno-assistenciais em saúde: da pirâmide ao círculo, uma possibilidade a ser explorada. Cad Saúde Pública. 1997;13:469-78.

3. Schraiber LB, Mendes-Gonçalves RB. Necessidades de saúde e atenção primária. In: Schraiber LB, Nemes MIB, MendesGonçalves RB, orgs. Saúde do Adulto: Programas e Ações na Unidade Básica. São Paulo: Hucitec; 1996. p. 29-47.

4. Hortale VA, Pedroza M, Rosa MLG. Operacionalizando as categorias acesso e descentralização na análise de sistemas de saúde. Cad Saúde Pública. 2000;16:231-9.

5. Cohn A, Nunes E, Jacobi PR, Karsch US. O acesso em discussão: o viés da racionalidade e o viés da carência. In: A saúde como direito e como serviço. São Paulo: Cortez Editora; 1991. p. 67-94.

6. Vellozo VRO, Souza RG. Acesso e hierarquização um caminho (re)construído. In: Bodstein R, org. Serviços locais de saúde: construção de atores e políticas. Rio de Janeiro: RelumeDumará; 1993. p. 93-116.

7. Franco TB, Bueno WS, Merhy EE. O acolhimento e os processos de trabalho em saúde: o caso de Betim, Minas Gerais, Brasil. Cad Saúde Pública. 1999;15:345-53.

8. Feliciano KVO, Kovacs $\mathrm{MH}$. Concepções maternas sobre a diarréia infantil. J Pediatr (Rio J). 2001;77:487-95.

9. Pinheiro R. As práticas do cotidiano na relação oferta e demanda dos serviços de saúde: um campo de estudo e construção da integralidade. In: Pinheiro R, Mattos RA, orgs. Os sentidos da integralidade na atenção e no cuidado à saúde. Rio de Janeiro: UERJ, IMS: ABRASCO; 2001. p. 65-112.

10. Felisberto $E$, Leal C, Samico IC. Referência na atenção pediátrica: uma "Emergência" em Pernambuco. Rev IMIP. 1994;9:61-9.

11. Aquino LA. Avaliação da acessibilidade à atenção médica prestada no Hospital Municipal Jesus - RJ [dissertação]. Rio de Janeiro (RJ): Instituto Fernandes Figueira da Fundação Oswaldo Cruz; 1996.

12. Feliciano KVO, Kovacs MH. Organização das práticas de saúde e vulnerabilidade à diarréia infantil. J Pediatr (Rio J). 2000;76: 27-36.

13. Victora CG, Barros FC. Amostragem. In: Epidemiologia da saúde infantil: um manual para diagnósticos comunitários. São Paulo: Hucitec-Unicef; 1991. p. 53-78.

14. Bardin L. Análise de conteúdo. Lisboa: Edições 70; 1977.

15. Deslandes SF. Concepções em pesquisa social: articulações com o campo da avaliação em serviços de saúde. Cad Saúde Pública. 1997;13:103-7.

Correspondence:

Maria Helena Kovacs

Rua Setúbal, 860 B/1103 - Boa Viagem

CEP 51030-010 - Recife, PE, Brazil

Tel. : +55 (81) 3423.6851 